Jurnal Gizi Klinik Indonesia

Vol. 17 No. 2, Oktober 2020 (79-86)

ISSN 1693-900X (Print), ISSN 2502-4140 (Online)

Tersedia online di https://jurnal.ugm.ac.id/jgki

DOI: https://doi.org/10.22146/ijcn.46304

\title{
Perbedaan asupan makan balita di perkotaan dan perdesaan pada provinsi dengan beban gizi ganda
}

Differences in food intake among children under five years in urban and rural areas in provinces with double burden of malnutrition

\author{
Puji Lestari $^{1}$, Susetyowati ${ }^{2}$, Mei Neni Sitaresmi ${ }^{3}$ \\ ${ }^{1}$ Program Studi Gizi, Fakultas Psikologi dan Kesehatan, Universitas Islam Negeri Walisongo, Semarang \\ 2 Departemen Gizi dan Kesehatan, Fakultas Kedokteran, Kesehatan Masyarakat, dan Keperawatan, Universitas Gadjah Mada, Yogyakarta \\ ${ }^{3}$ Departemen Ilmu Kesehatan Anak, Fakultas Kedokteran, Kesehatan Masyarakat, dan Keperawatan, Universitas Gadjah Mada, Yogyakarta
}

\begin{abstract}
Background: The double burden of malnutrition is one of the nutritional problems in children at national and global levels. Food intake is the main cause of the double burden of malnutrition. Differences in residence in urban and rural areas will affect food access which will have an impact on different food intake. Objective: To analyze the differences in energy, protein, fat, and carbohydrate intake of children under-fives in urban and rural areas in provinces with the double burden of malnutrition. Methods: This research used secondary data analysis using the Total Diet Study (TDS) 2014. The subjects of this study were 813 children in provinces with a dual burden of malnutrition that fulfilled the inclusion and exclusion criteria. Provinces with the double burden of malnutrition are provinces with a prevalence of underweight children aged $\geq 24-59$ months at $>22.36 \%$ and a prevalence of overweight children age $\geq 24-59$ months at $>1.23 \%$. Total Diet Study (TDS) data will provide information on food intake of children through recall results, differences in residence obtained from district classification data, the double burden of malnutrition data obtained from children nutritional status is overweight and underweight based on weight and age data of children processed using WHO-ANTRO software. Results: The average intake of energy, protein, and fat in the urban area are higher than in a rural area, but the average carbohydrate intake in an urban area is lower than in a rural area. The average intake of energy in urban was $1300.01 \mathrm{kcal}$, in rural areas was $1223.23 \mathrm{kcal}(p=0.0008)$. The average intake of protein in urban was $55.03 \mathrm{~g}$, in rural areas was $47.67 \mathrm{~g}(p<0.0001)$. The average intake of fat in urban was $47.99 \mathrm{~g}$, in rural areas was $37.12 \mathrm{~g}(p<0.0001)$. The average intakes of carbohydrate in urban were $163.61 \mathrm{~g}$, in rural areas was $178.88 \mathrm{~g}(\mathrm{p}=0.0042)$. Conclusions: There are differences in energy, protein, fat, and carbohydrate intake of children under five years in urban and rural areas in provinces with the double burden of malnutrition.
\end{abstract}

KEYWORDS: children under five; double burden of malnutrition; food intake; rural; urban

\begin{abstract}
ABSTRAK
Latar belakang: Beban gizi ganda merupakan salah satu masalah gizi pada balita di tingkat nasional maupun global. Asupan makanan merupakan penyebab utama terjadinya beban gizi ganda. Perbedaan tempat tinggal (perkotaan dan perdesaan) akan mempengaruhi akses pangan yang berdampak pada perbedaan asupan makanan. Tujuan: Tujuan penelitian ini untuk mengetahui perbedaan asupan energi, karbohidrat, protein, dan lemak balita di perkotaan dan perdesaan pada provinsi dengan beban gizi ganda. Metode: Penelitian ini menggunakan data sekunder yaitu data studi diet total (SDT) 2014 dengan jumlah subjek 813 balita di provinsi dengan beban gizi ganda yang memenuhi kriteria inklusi dan eksklusi. Provinsi dengan beban gizi ganda adalah provinsi dengan prevalensi balita (usia $\geq 24-59$ bulan) berat badan kurang yang lebih besar dari $22,36 \%$ dan berat badan berlebih yang lebih besar dari 1,23\%. Data SDT memberikan informasi rerata asupan makanan balita melalui hasil recall, perbedaan tempat tinggal diperoleh dari data klasifikasi kelurahan, data beban gizi ganda diperoleh dari status gizi balita yaitu berat badan lebih dan berat badan kurang berdasarkan data berat badan dan umur balita yang diolah menggunakan software WHO-ANTRO. Hasil: Rerata asupan energi pada balita di perkotaan (1.300,01 kcal) lebih besar dibandingkan di perdesaan $(1.223,23 \mathrm{kcal})(p=0,0008)$. Demikian
\end{abstract}

Korespondensi: Puji Lestari, Program Studi Gizi, Fakultas Psikologi dan Kesehatan, UIN Walisongo Semarang, Jl. Prof. Hamka (Kampus III), Ngaliyan, Kota Semarang, Jawa Tengah, Indonesia,e-mail: p.lestari@walisongo.ac.id

Cara sitasi: Lestari P, Susetyowati, Sitaresmi MN. Perbedaan asupan makan balita di perkotaan dan perdesaan pada provinsi dengan beban gizi ganda. Jurnal Gizi Klinik Indonesia. 2020;17(2):79-86. doi: 10.22146/ijen.46304 
juga dengan rerata asupan protein dan lemak yang ditemukan lebih besar pada balita di perkotaan daripada perdesaan (55,03 $g$ vs. 46,67 g dan 47,99 g vs. 37,12 g) ( $<<0,0001)$. Sebaliknya, rerata asupan karbohidrat pada balita di perkotaan lebih rendah dibandingkan perdesaan (163,61 g vs. 178,88 g; p=0,0042). Simpulan: Rerata asupan energi, protein, lemak, dan karbohidrat balita berbeda bermakna antara di perkotaan dan perdesaan pada provinsi dengan beban gizi ganda.

KATA KUNCI: balita; beban gizi ganda; asupan makanan; perdesaan; perkotaan

\section{PENDAHULUAN}

Beban gizi ganda adalah masalah gizi berupa berat badan kurang dan berat badan lebih yang terjadi dalam satu populasi (1). Beban gizi ganda ini masih menjadi masalah gizi pada tingkat nasional maupun global. Berdasarkan data World Health Organization (WHO), tren berat badan kurang pada usia balita dari tahun 2000-2015 di tingkat global mengalami penurunan, tetapi masih termasuk dalam kategori bermasalah karena prevalensi yang masih dalam kisaran 10-19\%. Pada tahun 2015, berat badan kurang sebesar 13,9\% atau sekitar 93,4 juta. Sementara tren berat badan lebih pada usia balita di tingkat global dari tahun 2000-2015 terjadi peningkatan. Pada tahun 2000, kasus berat badan lebih sebesar 30,1 juta menjadi 6,2\% atau sekitar 41,6 juta pada tahun $2015(1,2)$.

Berdasarkan data Badan Penelitian dan Pengembangan Kesehatan (Balitbangkes), pada tahun 2013 prevalensi balita dengan berat badan kurang sebesar $13,9 \%$ dan berat badan sangat kurang sebesar 5,7\%. Jika dibandingkan prevalensi tahun 2007 dan tahun 2010, maka prevalensi balita dengan berat badan kurang tahun 2013 meningkat. Prevalensi berat badan lebih menurut $\mathrm{BB} / \mathrm{U}$ pada balita di Indonesia tahun 2010 sebesar 5,8\%, kemudian tahun 2013 mengalami sedikit penurunan menjadi 4,5\% (3). Berdasarkan data Studi Diet Total (SDT) tahun 2014, prevalensi berat badan kurang balita usia $\geq 24-59$ bulan sebesar $22,36 \%$ dan prevalensi berat badan lebih sebesar 1,23\%. Provinsi dengan prevalensi balita berat badan kurang dan berat badan lebih di atas prevalensi nasional adalah provinsi Sumatera Utara, Riau, Jambi, Kalimantan Barat, Maluku, dan Papua (4).

Berbagai masalah yang timbul karena beban gizi ganda tercermin dari prevalensi kejadian berat badan kurang dan lebih pada balita. Berat badan kurang menyebabkan gangguan pertumbuhan dan perkembangan fisik, serta meningkatkan angka kematian. Sementara itu, berat badan lebih menyebabkan peningkatan risiko penyakit tidak menular dan mengurangi kualitas hidup secara keseluruhan (5). Berbagai faktor dapat menjadi penyebab beban gizi ganda, antara lain asupan makanan individu, tingkat pendidikan, status pekerjaan, ukuran rumah tangga, status sosial, rasio ketergantungan, and total fertility rate (TFR) $(6,7)$. Salah satu penyebab dari beban gizi ganda adalah asupan makanan individu, asupan makanan akan berbeda berdasarkan tempat tinggal karena tempat tinggal akan mempengaruhi akses pangan. Perbedaan tempat tinggal yang dimaksud adalah tempat tinggal di daerah perkotaan atau perdesaan $(8,9)$.

Hasil studi di Amerika menyebutkan bahwa penduduk usia 2-11 tahun di perkotaan lebih banyak konsumsi energi dan susu yaitu sekitar 2-3 cangkir/hari sedangkan pada usia 12-19 tahun lebih rendah konsumsi buah sekitar $320 \mathrm{~g} /$ hari. Anak-anak perkotaan berusia 6 sampai 11 tahun mengonsumsi energi lebih tinggi yaitu $1.934,8 \mathrm{kcal}$ sedangkan di perdesaan sebesar 1.844,1 kcal (10). Penelitian di Afrika Selatan menunjukan bahwa asupan lemak jenuh dan tak jenuh ganda lebih tinggi di perkotaan dibandingkan perdesaan. Asupan lemak dari makanan antara perkotaan dan perdesaan tercermin dalam total profil fatty acid (FA), fosfolipid, dan membran sel darah merah yang menunjukkan bahwa total lemak dan $\alpha$-linolenic acid (ALA) anak-anak perdesaan lebih rendah dari anak perkotaan. Selain itu, total lemak, asupan lemak omega-3, dan omega-6 di perdesaan ditemukan lebih rendah dibandingkan pedoman yang dianjurkan di Afrika Selatan (11).

Studi sebelumnya telah banyak yang meneliti terkait asupan makan balita, tetapi data asupan makan balita belum pernah dianalisis pada provinsi dengan beban gizi ganda. Dengan demikian, tujuan penelitian ini adalah mengkaji perbedaan asupan makan balita di perkotaan dan perdesaan pada provinsi dengan beban gizi ganda. 


\section{BAHAN DAN METODE}

\section{Desain dan subjek}

Penelitian ini adalah penelitian kuantitatif yaitu secondary data analysis dengan menggunakan data Studi Diet Total (SDT) tahun 2014 dan desain penelitian crosssectional yang dilakukan pada bulan Januari-April 2017. Populasi penelitian ini adalah seluruh rumah tangga di 33 provinsi dan 497 kabupaten atau kota yaitu 46.238 rumah tangga dengan jumlah balita (usia $\geq 24-59$ bulan) di 33 provinsi sebesar 4.112 balita (4). Subjek penelitian ini adalah seluruh balita di provinsi dengan beban gizi ganda yang memenuhi kriteria inklusi yaitu balita berusia lebih dari atau sama dengan 24-59 bulan sedangkan kriteria eksklusi yaitu balita dalam keadaan sakit saat recall asupan makan dilakukan.

Jumlah balita (usia $\geq 24-59$ bulan) di provinsi dengan beban gizi ganda sebesar 820 balita, tetapi ada tujuh balita yang sakit saat recall dilakukan sehingga sampel penelitian ini sebesar 813 balita dari enam provinsi yang mengalami beban gizi ganda. Provinsi tersebut terdiri dari 330 balita di Provinsi Sumatera Utara, 121 balita di Provinsi Riau, 102 balita di Provinsi Jambi, 88 balita di Provinsi Kalimantan Barat, 88 balita di Provinsi Maluku, dan 84 balita di Provinsi Papua. Perbedaan tempat tinggal (perkotaan dan perdesaan) diperoleh dari data klasifikasi kelurahan.

Penelitian ini dilakukan setelah memperoleh ethical clearance dari Komite Etik Penelitian Biomedis Fakultas Kedokteran Universitas Gadjah Mada dengan Nomor: KE/FK/0199/EC/2017 sebagai syarat kelayakan penelitian dan mendapatkan ijin dari Balitbangkes Kementerian Kesehatan Republik Indonesia (RI) untuk menggunakan data SDT sebagai variabel penelitian.

\section{Pengumpulan dan pengukuran data}

Status gizi balita. Data beban gizi ganda diperoleh dari status gizi balita berdasarkan data berat badan (BB) dan umur ( $\mathrm{U}$ ) balita untuk menghitung z-score BB/U yang diolah menggunakan software WHO-ANTRO. Status gizi dikategorikan menjadi berat badan kurang jika z-score BB/U kurang dari -2 SD dan berat badan lebih jika z-score BB/U jika lebih dari atau sama dengan 2 SD (5). Provinsi dengan beban gizi ganda adalah provinsi dengan prevalensi balita (usia $\geq 24-59$ bulan) dengan berat badan kurang sebesar lebih dari 22,36\% dan prevalensi balita (usia $\geq 24-59$ bulan) dengan berat badan lebih sebesar lebih dari 1,23\%.

Asupan makan balita. Data asupan makan menggunakan data Studi Diet Total (SDT) tahun 2014 yang diperoleh dengan recall 1×24 jam yanh kemudian diolah menggunkan software nutrisurvey. Data asupan makanan meliputi asupan energi (Kcal), karbohidrat (g), lemak (g), dan protein (g). Asupan makanan tersebut kemudian dilihat perbedaan antara balita di perkotaan dan perdesaan.

Karakteristik responden. Data karakteristik meliputi usia balita yang dikategorikan menjadi usia lebih dari atau sama dengan 24-36 bulan dan usia lebih dari 36-59 bulan; pendidikan ibu dikategorikan menjadi rendah jika di bawah SMA dan tinggi jika lebih dari SMA; pekerjaan orang tua dikategorikan menjadi tidak bekerja, PNS/TNI/Polri/BUMN, pegawai swasta, wiraswasta, petani, nelayan, buruh, lainnya; serta ukuran rumah tangga dikategorikan menjadi kecil jika anggota rumah tangga kurang dari atau sama dengan 4 orang dan besar jika anggota keluarga lebih dari 4 orang.

\section{Analisis data}

Analisis univariat meliputi karakteristik responden yaitu usia balita, pendidikan ibu, pekerjaan orang tua, dan ukuran rumah tangga serta rerata asupan makanan balita di perkotaan dan perdesaan. Analisis bivariat meliputi perbedaan asupan makanan balita di perkotaan dan perdesaan, pengaruh pendidikan ibu, pekerjaan orang tua, dan ukuran rumah tangga terhadap asupan makanan balita. Uji normalitas data dilakukan dengan Shapiro-Wilk terlebih dahulu, karena data tidak normal maka digunakan uji Mann-Whitney. Data penelitian ini diolah dengan menggunakan software STATA.

\section{HASIL}

Prevalensi berat badan kurang balita di perkotaan pada provinsi dengan beban gizi ganda sebesar 21,78\% sedangkan di perdesaan sebesar 27,31\%. Prevalensi berat badan lebih di perkotaan pada provinsi dengan beban gizi ganda sebesar 3,99\% sedangkan di perdesaan 
sebesar 0,62\%. Karakteristik responden pada Tabel 1 menunjukkan bahwa pendidikan ibu yang rendah lebih banyak ditemukan di perdesaan $(65,50 \%)$ dibandingkan di perkotaan (44,79\%). Sebaliknya, pendidikan ibu yang tinggi lebih banyak ditemukan di perkotaan sebesar 55,21\%. Ukuran rumah tangga yaitu banyaknya anggota keluarga, kategori ukuran rumah tangga besar

Tabel 1. Karakteristik responden penelitian $(n=813)$

\begin{tabular}{lrr}
\hline \multicolumn{1}{c}{ Variabel } & $\begin{array}{r}\text { Perkotaan } \\
(\mathbf{n = 3 2 6})\end{array}$ & $\begin{array}{r}\text { Perdesaan } \\
(\mathbf{n = 4 8 7})\end{array}$ \\
\cline { 2 - 3 } & $\mathbf{n ~ ( \% )}$ & $\mathbf{n ~ ( \% )}$ \\
\hline Balita (bulan) & & \\
$\geq 24-36$ & $120(36,81)$ & $166(34,08)$ \\
$>36-59$ & $206(63,19)$ & $321(65,91)$ \\
Pendidikan ibu & & \\
$\quad$ Rendah & $146(44,79)$ & $319(65,50)$ \\
Tinggi & $180(55,21)$ & $168(34,50)$ \\
Ukuran rumah tangga & & \\
Kecil & $131(40,18)$ & $190(39,01)$ \\
Besar & $195(59,82)$ & $297(60,99)$ \\
Status pekerjaan ibu & & \\
Tidak bekerja & $204(62,58)$ & $249(51,13)$ \\
PNS/TNI/Polri/BUMN & $28(8,59)$ & $15(3,08)$ \\
Pegawai swasta & $14(4,29)$ & $13(2,67)$ \\
Wiraswasta & $27(8,28)$ & $26(5,34)$ \\
Petani & $20(6,13)$ & $157(32,24)$ \\
Nelayan & $1(0,31)$ & $1(0,21)$ \\
Buruh & $3(0,92)$ & $5(1,03)$ \\
Lainnya & $29(8,90)$ & $21(4,31)$ \\
Status pekerjaan ayah & & \\
Tidak bekerja & $11(3,37)$ & $23(4,72)$ \\
PNS/TNI/Polri/BUMN & $57(17,48)$ & $28(5,75)$ \\
Pegawai swasta & $33(10,12)$ & $31(6,37)$ \\
Wiraswasta & $119(36,50)$ & $82(16,84)$ \\
Petani & $37(11,35)$ & $246(50,51)$ \\
Nelayan & $17(5,21)$ & $27(5,54)$ \\
Buruh & $37(11,35)$ & $33(6,78)$ \\
Lainnya & $15(4,60)$ & $17(3,49)$ \\
\hline & & \\
& & \\
& &
\end{tabular}

terjadi di perkotaan $(59,82 \%)$ dan juga di perdesaan $(60,99 \%)$. Mayoritas ibu tidak bekerja baik di perdesaan $(51,13 \%)$ maupun di perkotaan $(62,58 \%)$, di perdesaan profesi kedua terbesar adalah sebagai petani (32,24\%). Sementara mayoritas ayah di perkotaan bekerja sebagai wiraswasta $(36,50 \%)$ sedangkan di perdesaan bekerja sebagai petani $(50,51 \%)$.

Rerata asupan makan yang sudah memenuhi bahkan melebihi angka kecukupan gizi (AKG) yang dianjurkan adalah asupan energi balita usia lebih dari atau sama dengan 24-36 bulan di perkotaan dan perdesaan; asupan protein balita di perkotaan dan perdesaan; dan asupan karbohidrat balita usia lebih dari atau sama dengan 24-36 bulan di perdesaan (Tabel 2). Tabel 3 menunjukkan bahwa rerata asupan energi, protein, dan lemak pada balita di perkotaan lebih besar secara signifikan dibandingkan asupan energi, protein, dan lemak pada balita di perdesaan. Sebaliknya, rerata asupan karbohidrat pada balita di perkotaan lebih kecil dibandingkan di perdesaan $(\mathrm{p}=0,0042)$.

Sementara berdasarkan Tabel 4, variabel karakteristik yang berpengaruh terhadap asupan balita adalah pendidikan ibu dan ukuran rumah tangga. Lebih detail, hasil analisis menunjukkan bahwa pendidikan ibu berpengaruh pada perbedaan asupan energi, protein, dan lemak balita. Ibu yang berpendidikan tinggi menunjukkan rerata asupan energi, protein, dan lemak balita yang lebih tinggi dibandingkan ibu dengan pendidikan rendah. Selain itu, ukuran rumah tangga berpengaruh pada perbedaan asupan lemak yaitu jumlah anggota keluarga yang kecil memiliki rerata asupan lemak yang lebih tinggi dibandingkan keluarga dengan jumlah anggota keluarga besar. Pekerjaan ibu dan ayah tidak berpengaruh pada perbedaan asupan energi, protein, lemak, dan karbohidrat balita.

Tabel 2. Asupan makan balita berdasarkan AKG dan recall di perkotaan dan perdesaan pada provinsi dengan beban gizi ganda

\begin{tabular}{lcccccccc}
\hline \multirow{2}{*}{ Tempat tinggal } & \multicolumn{2}{c}{ Energi (kcal) } & \multicolumn{2}{c}{ Protein $(\mathrm{g})$} & \multicolumn{2}{c}{ Lemak (g) } & \multicolumn{2}{c}{ Karbohidrat (g) } \\
\cline { 2 - 7 } & AKG & Recall & AKG & Recall & AKG & Recall & AKG & Recall \\
\hline Usia $\geq 24-36$ bulan & 1.125 & & 26 & & 44 & & 155 & \\
Perkotaan & & $1.176,85$ & & 47,29 & & 43,29 & & 149,78 \\
Perdesaan & & $1.141,97$ & & 41,10 & & 35,37 & & 166,79 \\
Usia $>36-59$ bulan & 1.600 & & \multirow{2}{*}{35} & & 62 & & 220 & \\
Perkotaan & & $1.369,11$ & & 59,40 & & 50,26 & & 172,30 \\
$\quad$ Perdesaan & & $1.266,94$ & & 49,64 & & 38,32 & & 184,71 \\
\hline
\end{tabular}


Tabel 3. Perbedaan asupan makan balita di perkotaan dan perdesaan pada provinsi dengan beban gizi ganda

\begin{tabular}{lllc}
\hline Asupan makan & Tempat tinggal & \multicolumn{1}{c}{ Rerata \pm SD } & $\mathbf{p}^{*}$ \\
\hline Energi & Perkotaan & $1.300,01(750,93-2.572,05)$ & 0,0008 \\
& Perdesaan & $1.223,23(751,34-2.592,80)$ & \\
Protein & Perkotaan & $55,03(18,14-185,59)$ & $<0,0001$ \\
& Perdesaan & $46,67(2,81-213,15)$ & \\
Lemak & Perkotaan & $47,99(7,11-143,30)$ & $<0,0001$ \\
& Perdesaan & $37,12(0,79-199,27)$ & \\
Karbohidrat & Perkotaan & $163,61(52,10-378,75)$ & 0,0042 \\
& Perdesaan & $178,88(43,19-535,19)$ & \\
\hline
\end{tabular}

*Uji Mann-Whitney

Tabel 4. Asupan makan balita berdasarkan pendidikan ibu, pekerjaan orang tua, dan ukuran rumah tangga pada provinsi dengan beban gizi ganda

\begin{tabular}{|c|c|c|c|}
\hline Variabel luar & Asupan makan & Rerata (min-maks) & $\mathbf{p}^{*}$ \\
\hline \multicolumn{4}{|l|}{ Pendidikan ibu } \\
\hline Rendah & Energi (kcal) & $1.184,09(750,93-2592,80)$ & 0,0137 \\
\hline Tinggi & & $1.233,30(751,34-2572,05)$ & \\
\hline Rendah & Protein (g) & $42,21(2,81-153,52)$ & 0,0001 \\
\hline Tinggi & & $49,33(14,17-213,15)$ & \\
\hline Rendah & Lemak (g) & $36,15(0,79-199,27)$ & 0,0001 \\
\hline Tinggi & & $41,09(4,45-137,66)$ & \\
\hline Rendah & Karbohidrat (g) & $166,21(50,28-535,19)$ & 0,0770 \\
\hline Tinggi & & $162,83(43,19-425,18)$ & \\
\hline \multicolumn{4}{|l|}{ Pekerjaan ibu } \\
\hline Tidak bekerja & Energi (kcal) & $1.200,51(751,34-2.465,34)$ & 0,5266 \\
\hline Bekerja & & $1.213,68(750,93-2.592,80)$ & \\
\hline Tidak bekerja & Protein $(g)$ & $45,35(2,80-185,59)$ & 0,5367 \\
\hline Bekerja & & $46,45(6,45-213,15)$ & \\
\hline Tidak bekerja & Lemak (g) & $37,48(0,78-199,27)$ & 0,9947 \\
\hline Bekerja & & $37,38(1,34-131,21)$ & \\
\hline Tidak bekerja & Karbohidrat (g) & $164,47(50,28-535,19)$ & 0,1149 \\
\hline Bekerja & & $164,97(43,19-436,69)$ & \\
\hline \multicolumn{4}{|l|}{ Pekerjaan ayah } \\
\hline Tidak bekerja & Energi (kcal) & $1.314,33(790,22-2.198,61)$ & 0,1149 \\
\hline Bekerja & & $1.203,27(750,93-2.592 .80)$ & \\
\hline Tidak bekerja & Protein $(g)$ & $51,33(6,21-185,59)$ & 0,5636 \\
\hline Bekerja & & $45,33(2,81-213,15)$ & \\
\hline Tidak bekerja & Lemak (g) & $43,36(5,12-89,52)$ & 0,2844 \\
\hline Bekerja & & $37,13(0,78-199,27)$ & \\
\hline Tidak bekerja & Karbohidrat (g) & $177,59(83,52-326,26)$ & 0,2329 \\
\hline Bekerja & & $163,59(43,19-535,19)$ & \\
\hline \multicolumn{4}{|c|}{ Ukuran rumah tangga } \\
\hline Kecil & Energi (kcal) & $1.208,99(750,93-2.572,05)$ & 0,3928 \\
\hline Besar & & $1.201,80(751,34-2.592,80)$ & \\
\hline Kecil & Protein $(g)$ & $45,89(5,77-166,62)$ & 0,3768 \\
\hline Besar & & $45,07(2,81-213,15)$ & \\
\hline Kecil & Lemak (g) & $40,97(2,08-199,27)$ & 0,0004 \\
\hline Besar & & $35,76(0,79-143,30)$ & \\
\hline Kecil & Karbohidrat (g) & $162,84(50,28-378,75)$ & 0,1327 \\
\hline Besar & & $166,30(43,19-535,19)$ & \\
\hline
\end{tabular}

*Uji Mann-Whitney 


\section{BAHASAN}

Berdasarkan data Studi Diet Total Balitbangkes tahun 2014 tentang rerata asupan makan balita pada tingkat nasional, rerata asupan energi balita tingkat nasional di perkotaan sebesar $1.190 \mathrm{kcal}$ dan di perdesaan sebesar $1.081 \mathrm{kcal}$. Dengan demikian, rerata asupan energi balita di perkotaan lebih besar daripada perdesaan. Hal tersebut sejalan dengan hasil penelitian ini bahwa rerata asupan energi balita di perkotaan sebesar 1.300,01 kcal sedangkan di perdesaan sebesar 1.223,23 kcal, jadi rerata asupan energi balita di perkotaan lebih besar dibandingkan di perdesaan pada provinsi dengan beban gizi ganda.

Berbeda dengan hasil studi sebelumnya yang menyebutkan bahwa asupan energi lebih banyak pada balita di perdesaan daripada di perkotaan (6). Namun demikian, tetap mencerminkan adanya perbedaan asupan energi di perkotaan dan perdesaan sesuai dengan hasil penelitian ini bahwa ada perbedaan asupan energi balita di perkotaan dan perdesaan pada provinsi dengan beban gizi ganda. Lebih lanjut, penelitian di Korea memperoleh hasil bahwa rerata asupan energi di perdesaan lebih rendah dari rekomendasi diet Korea yaitu sekitar 60-80\% sedangkan di perkotaan asupan energi lebih mendekati rekomendasi tersebut. Dengan demikian, asupan energi di perkotaan lebih baik daripada di perdesaan (12).

Rerata asupan protein tingkat nasional di perkotaan sebesar 39,2 g yang lebih besar dibandingkan di perdesaan $(34,4 \mathrm{~g})$. Hal ini sejalan dengan hasil penelitian ini bahwa rerata asupan protein di perkotaan lebih besar daripada di perdesaan pada provinsi dengan beban gizi ganda (4). Sejalan dengan studi lain yang melaporkan hasil konsumsi susu sekitar 2-3 cangkir/hari lebih banyak di perkotaan dibandingkan perdesaan (6). Penelitian di China juga memperoleh hasil bahwa anak-anak perkotaan lebih banyak konsumsi daging, unggas, dan telur. Konsumsi daging dan unggas di perkotaan sebesar 432,43 g sedangkan di perdesaan sebesar 367,36 g sementara konsumsi telur di perkotaan sebesar 151,23 g sedangkan di perdesaan sebesar 144,78 g (13).

Rerata asupan lemak tingkat nasional di perkotaan sebesar 46,9 g sedangkan di perdesaan sebesar 36,7 g. Hal tersebut sejalan dengan hasil penelitian ini bahwa rerata asupan lemak di perkotaan lebih besar daripada di perdesaan pada provinsi dengan beban gizi ganda. Studi terdahulu menemukan bahwa total lemak dan $\alpha$-linolenic acid (ALA) anak-anak perdesaan lebih rendah daripada anak perkotaan. Selain total lemak, asupan lemak omega-3 dan omega-6 di perdesaan juga lebih rendah dibandingan pedoman yang dianjurkan di Afrika Selatan (11). Penelitian di daerah perkotaan di Brasil Selatan menunjukkan bahwa konsumsi sayuran anak-anak di bawah tingkat yang direkomendasikan sedangkan asupan makanan dari kelompok minyak dan lemak melebihi rekomendasi. Dengan demikian, asupan lemak anak-anak di perkotaan kurang baik (14).

Rerata asupan karbohidrat tingkat nasional di perkotaan sebesar 153,7 g sedangkan di perdesaan sebesar 142,1 g sehingga rerata asupan karbohidrat di perkotaan lebih besar daripada di perdesaan. Hal tersebut bertolak belakang dengan hasil penelitian ini, bahwa rerata asupan karbohidrat di perkotaan $(163,61 \mathrm{~g})$ lebih kecil daripada di perdesaan pada provinsi dengan beban gizi ganda. Sejalan dengan hasil studi di China bahwa konsumsi sereal di perkotaan sebesar 1.508,06 g sedangkan diperdesaan sebesar 1.917,25 g sehingga dapat disimpulkan bahwa konsumsi sumber karbohidrat lebih banyak di perdesaan (13). Konsumsi pangan sumber karbohidrat di perdesaan lebih tinggi karena pekerjaan masyarakat perdesaan cenderung membutuhkan banyak energi dibandingkan pekerjaan masyarakat perkotaan. Oleh karena itu, kebutuhan energi masyarakat perdesaan cenderung lebih besar dan makanan masyarakat perdesaan seringkali lebih banyak didominasi pangan pokok (sumber energi yang relatif murah) dibandingkan makanan masyarakat perkotaan (15).

Lebih lanjut, hasil analisis studi ini menunjukkan rerata asupan energi, protein, dan lemak balita lebih besar pada ibu berpendidikan tinggi sedangkan asupan karbohidrat balita lebih banyak pada ibu dengan pendidikan rendah. Pendidikan ibu akan mempengaruhi pengetahuan dan pola asuh anak yang akan berdampak pada asupan makanan balita (16). Rerata asupan energi, protein, lemak, dan karbohidrat balita lebih banyak pada ibu yang bekerja dan ayah yang tidak bekerja. Hasil studi ini tidak menunjukkan perbedaan asupan energi, protein, lemak dan karbohidrat balita pada ayah dan ibu yang bekerja maupun tidak bekerja. Hal tersebut tidak sejalan 
dengan hasil penelitian yang menyatakan bahwa status pekerjaan yang bagus akan meningkatkan pemasukan keluarga yang akan berpengaruh pada asupan makanan individu (6). Penelitian di Malaysia menyimpulkan bahwa pendapatan yang rendah akan menurunkan daya beli makanan yang berkualitas seperti kurang bergizi dan padat energi dengan sumber utama dari karbohidrat (17). Hal ini sejalan dengan hasil penelitian ini bahwa asupan karbohidrat ditemukan lebih banyak pada balita di perdesaan dengan mayoritas pekerjaan ayah sebagai petani, yang dapat disimpulkan bahwa pendapatan keluarga di perdesaan lebih rendah daripada di perkotaan yang mayoritas bekerja sebagai wiraswasta. Demikian juga dengan rerata asupan energi, protein, dan lemak balita yang lebih banyak pada keluarga dengan ukuran rumah tangga kecil sedangkan rerata asupan karbohidrat lebih banyak pada keluarga dengan ukuran rumah tangga besar. Ukuran rumah tangga kecil dan besar ini berpengaruh pada asupan lemak balita, tetapi tidak berpengaruh pada asupan energi, protein, dan karbohidrat balita.

Perbedaan asupan makanan balita di perkotaan dan perdesaan ini juga dipengaruhi oleh akses pangan masyarakat yang akan berakibat pada ketersediaan pangan di lingkungan tersebut. Penelitian di Texas memperoleh hasil bahwa jarak rumah ke supermarket tidak berpengaruh signifikan terhadap asupan buah dan sayur di perkotaan, tetapi berpengaruhi signifikan terhadap asupan buah dan sayur di perdesaan (8). Penelitian di Minnesotans tentang pengaruh akses sistem pangan di perkotaan dan perdesaan terhadap pangan sehat, diperoleh hasil bahwa akses pangan meliputi ketersediaan infrastruktur, keterlibatan masyarakat, dan hubungan timbal balik penyedia makanan di tempat tersebut memiliki pengaruh yang berbeda di perkotaan dan perdesaan. Penduduk perdesaan lebih mengandalkan toko kelontong, berkebun, berburu, dan sistem pertukaran informal sedangkan penduduk perkotaan lebih mengandalkan toko dan supermarket sehingga akan berpengaruh pada pemilihan bahan makanan keluarga (9). Penelitian lain tentang akses pangan di perkotaan dan perdesaan menyebutkan bahwa makanan yang tersedia di supermarket dan toko grosir lebih mahal daripada toko kelontong, tetapi cenderung lebih sehat seperti adanya sayuran organik, produk rendah lemak, berserat tinggi, dan sebagainya. Di perdesaan, toko kelontong belum sepenuhnya menyediakan makanan sehat dengan harga yang terjangkau sehingga makanan sehat dalam rumah tangga belum terpenuhi (18).

\section{SIMPULAN DAN SARAN}

Rerata asupan energi, protein, dan lemak lebih besar pada balita di perkotaan sedangkan rerata asupan karbohidrat lebih besar di perdesaan. Ada perbedaan asupan energi, lemak, protein, dan karbohidrat balita di perkotaan dan perdesaan pada provinsi dengan beban gizi ganda. Upaya yang dapat dilakukan untuk mengatasi perbedaan asupan makanan balita adalah memberikan edukasi tentang pentingnya peningkatan pendidikan calon ibu di perdesaan yang akan berpengaruh positif terhadap asupan energi, protein, lemak, dan karbohidrat balita. Selain itu, perlu peningkatan akses pangan di daerah perdesaan yang akan meningkatkan ketersediaan pangan di perdesaan serta sosialisasi kepada ibu balita tentang kesesuaian asupan makanan balita dengan kecukupan gizinya.

\section{UCAPAN TERIMA KASIH}

Peneliti berterima kasih kepada Balitbangkes RI yang telah memberikan akses pada data Studi Diet Total (SDT) tahun 2014.

\section{Pernyataan konflik kepentingan}

Peneliti menyatakan tidak ada konflik kepentingan dalam penelitian ini.

\section{RUJUKAN}

1. The World Bank Indonesia. Indonesia menghadapi beban gizi ganda malnutrisi. Jakarta: Bank Indonesia; 2012.

2. World Health Organization (WHO). Global and regional trends by UN regions, 1990-2025. Jeneva: WHO; 2016.

3. Badan Penelitian dan Pengembangan Kesehatan. Riset kesehatan dasar tahun 2013. Jakarta: Kementerian Kesehatan RI; 2013.

4. Badan Penelitian dan Pengembangan Kesehatan. Survei konsumsi makanan individu tahun 2014. Jakarta: Kementerian Kesehatan RI; 2014. 
5. Kementerian Kesehatan RI. Standar antropometri penilaian status gizi anak. Jakarta: Kementerian Kesehatan RI; 2010.

6. Djaiman SP, Fuada N. Faktor-faktor pembeda provinsi yang mengalami beban gizi ganda (BGG) pada anak balita di Indonesia. Jakarta: Pusat Teknologi Intervensi Kesehatan Masyarakat, Balitbangkes; 2015.

7. Hanandita W, Tampubolon G. The double burden of malnutrition in indonesia: social determinants and geographical variations. SSM Population Health. 2015;1:16-25. doi: 10.1016/j.ssmph.2015.10.002

8. Dean WR, Sharkey JR. Rural and urban differences in the associations between characteristics of the community food environment and fruit and vegetable intake. J Nutr Educ Behav. 2011;43(6):426-33. doi: 10.1016/j. jneb.2010.07.001

9. Smith C, Miller H. Accessing the food systems in urban and rural minnesotan communities. J Nutr Educ Behav. 2011;43(6):492-504. doi: 10.1016/j.jneb.2011.05.006

10. Liu JH, Jones SJ, Sun H, Probst JC, Merchant AT, Cavicchia P. Diet, physical activity, and sedentary behaviors as risk factors for childhood obesity: an urban and rural comparison. Child Obes. 2012;8(5):440-8. doi: 10.1089/chi.2012.0090

11. Ford R, Faber M, Kunneke E, Smuts CM. Prostaglandins, leukotrienes and essential fatty acids dietary fat intake and red blood cell fatty acid composition of children and women from three different geographical areas in South Africa. Prostaglandins, Leukotrienes and Essential Fatty Acids. 2016;109(2):13-21. doi: 10.1016/j.plefa.2016.04.003
12. Kim SH, Kim JY, Keen CL. Comparison of dietary patterns and nutrient intakes of elementary schoolchildren living in remote rural and urban areas in Korea: their potential impact on school performance. Nutrition Research. 2005;25(4):349-63. doi: 10.1016/j.nutres.2005.01.003

13. Liu H, Fang H, Zhao Z. Urban-rural disparities of child health and nutritional status in China from 1989 to 2006. Econ Hum Biol. 2013;11(3):294-309. doi: 10.1016/j. ehb.2012.04.010

14. Leal KK, Schneider BC, Gigante DP, Santos I, Assunção MCF. Diet quality of preschool children aged 2 to 5 years living in the urban area of Pelotas, Brazil. Rev Paul Pediatr. 2015;33(3):311-8. doi: 10.1016/j.rpped.2015.05.002

15. Apriani S, Baliwati YF. Faktor-faktor yang berpengaruh terhadap konsumsi pangan sumber karbohidrat di perdesaan dan perkotaan. Jurnal Gizi dan Pangan. 2011;6(3):200-7. doi: 10.25182/jgp.2011.6.3.200-207

16. Doku DT, Neupane S. Double burden of malnutrition: increasing overweight and obesity and stall underweight trends among Ghanaian women. BMC Public Health. 2015;15(670):1-9. doi: 10.1186/s12889-015-2033-6

17. Wong CY, Zalilah MS, Chua EY, Norhasmah S, Chin YS, Nur'asyura AS. Double-burden of malnutrition among the indigenous peoples (Orang Asli) of Peninsular Malaysia. BMC Public Health. 2015;15:680. doi: 10.1186/s12889015-2058-x

18. Liese AD, Weis KE, Pluto D, Smith E, Lawson A. Food store types, availability, and cost of foods in a rural environment. J Am Diet Assoc. 2007;107(11):1916-23. doi: 10.1016/j.jada.2007.08.012 